\title{
The Role of the Public Prosecutor in the United States ${ }^{1}$
}

Michael C. Kovac ${ }^{2}$

\section{ABSTRACT}

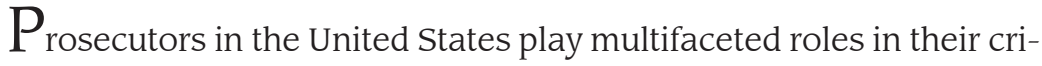
minal justice system. They provide guidance during the investigative stages of cases, lead the prosecution of cases in the country's adversarial proceedings, police their own profession, and lead legislative efforts aimed at making the system more just for all involved. There are separate prosecuting offices for the separate sovereignties located within the countries. Statutes, constitutions, and case law establish the rights and duties of those separate offices. All prosecuting offices in the United States share the pursuit of justice as their common goal.

Keywords: Prosecutor. United States. Nevada. Las Vegas.

\section{INTRODUCTION}

The role of the public prosecutor in the United States is in many ways similar to the role of prosecutors in other parts of the world. A prosecutor in the United States often does far more than the courtroom work often portrayed on television: the prosecutor provides guidance during investigations; the prosecutor engages in legislative activities designed to improve the criminal justice system; and the

1 Data de Recebimento: 17/12/2019. Data de Aceite: 29/05/2020.

2 Chief Deputy Attorney General, State of Nevada, Office of the Attorney General; Lecturer in Law, University of Southern California. Duquesne University, J.D., University of Pittsburgh-Johnstown (B.S.). The views expressed in this article are those of the author alone, not those of his employers or anyone else. E-mail:mkovac@ag.nv.gov 
prosecutor works to inform the public in a manner that gives the public confidence that the criminal justice system is designed to ensure justice and fairness for all. As the public's support for law enforcement policies shifts, from a hardline view of law-and-order to a more practical view with an emphasis on reform and rehabilitation (when appropriate), the public prosecutor's approach will have to shift as well.

\section{OVERVIEW OF THE PROSECUTOR'S ROLE IN THE UNITED STATES' CRIMINAL JUSTICE SYSTEM}

The United States' criminal justice system is an adversarial, common law system. The government is represented by public prosecutors, while the accused is represented by a defense attorney. The judge rules over issues of law, while (generally) a jury of the accused's peers (comprised of members of the public) performs the factfinding function and is ultimately responsible for determining whether the defendant is guilty of any of the charges levied by the government.

For any single location within the United States, it is likely that multiple public prosecution offices operate independently to prosecute those who commit crimes in that particular location. Take the city of Las Vegas, for example. That city is a part of Clark County, which is encompassed by the state of Nevada, which is one of the 50 states that make up the United States.

Each of those sovereignties has its own public prosecutors who have a duty to prosecute certain crimes within their respective jurisdictions. The Las Vegas City Attorney is the head prosecutor for the city. The Clark County District Attorney is the head prosecutor for the county. The Nevada Attorney General is the head prosecutor for the state. And the United States Attorney General is the head prosecutor for the country. In some jurisdictions, the head public prosecutor is 
appointed; ${ }^{3}$ in others, the position is filled by public vote. ${ }^{4}$

The powers and limitations of each of those offices are prescribed by the various ordinances, laws, and constitutions that create and define those offices. In all instances, "[t]he prosecutor is an administrator of justice, a zealous advocate, and an officer of the court." 5 For the most part, the roles of public prosecutors in the United States are consistent with those articulated by the United Nations Office on Drugs and Crime and the International Association of Prosecutors:

In most systems, the core functions of the prosecutors are the decision to prosecute and representation of the prosecution in court. Core functions in some jurisdictions may also encompass investigating crime, supervision of investigators' compliance with procedural rules, judicial interim release ("bail"), plea and sentence agreements, diversion of offenders to alternatives to prosecution, victim support, recommendations regarding sentence, the supervision of the execution of sentences and treatment of persons in custody. Additionally, in all systems the strategic role of prosecutors in criminal proceedings qualifies them to make recommendations concerning criminal justice policies. ${ }^{6}$

In an opinion issued in 1935, the United States Supreme Court addressed the role of the United States Attorney General:

The United States Attorney General is the representative not of an ordinary party of the controversy but, of a sovereignty whose obligation to govern impartially is as compelling as its obligation to govern at all; and whose interest, therefore, in a criminal prosecution is not that it shall win a case, but that justice shall be done. As such, he is in a peculiar and very definite sense the servant of the law, the twofold

3 See e.g., 28 U.S.C. § 541 (providing for appointment of United States Attorneys).

4 See e.g., NEV. REV. STAT. § 228.020 (providing for the election of the Attorney General for the State of Nevada).

5 American Bar Association, Criminal Justice Standards for the Prosecution Function, Standard 3-1.2(a) (4th ed.).

6 United Nations Office on Drugs and Crime, The Status and Role of Prosecutors: A United Nations Office on Drugs and Crime and International Association of Prosecutors Guide, at 1 (2014). 
aim of which is guilt shall not escape or innocence suffer. He may prosecute with earnestness and vigor - indeed, he should do so. But, while he may strike hard blows, he is not at liberty to strike foul ones. It is as much his duty to refrain from improper methods calculated to produce a wrongful conviction as it is to use every legitimate means to bring about a just one. ${ }^{7}$

These same principles are generally applicable with respect to all prosecutors in the United States; they do not represent the victim or any other individual. Instead, they generally represent the collective people of their respective jurisdictions.

The prosecutor's role in any given case will vary, depending on the circumstances of that particular case. For a relatively common case, such a simple battery case where the victim suffers nothing more than a black eye, an investigative agency will likely conduct the entire investigation before submitting it to the prosecuting office for prosecution. In such a case, the prosecutor will do little more than make a charging decision and, if the case is prosecuted, carry out the typical steps for moving the case through the court process. For a more complicated case, such as a murder case or complex fraud case, the prosecutor's role will likely extend far beyond the charging decision and courtroom work.

In those more complicated cases, investigative agencies often seek legal guidance from prosecutors in order to avoid having evidence they obtain declared inadmissible by the court. In order to appreciate this risk, a brief explanation of the relevant legal principles is necessary.

The United States Constitution provides citizens with a number of rights. For example, the Fourth Amendment protects citizens against unreasonable searches of their persons and effects, which generally requires that, prior to a search of an area where a defendant has a reasonable expectation of privacy, investigators have to obtain a

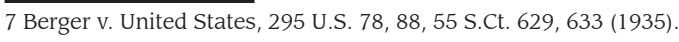


search warrant supported by probable cause. ${ }^{8}$ An investigator runs the risk that the court will exclude any evidence obtained in violation of these requirements. ${ }^{9}$ For this reason, among others, investigators often seek guidance from prosecutors to avoid such pitfalls.

In addition to assisting with investigations, prosecutors often issue statements to the media in order to inform the public about important cases. Furthermore, public prosecutors routinely participate in the legislative process in their ongoing efforts to address novel issues affecting criminal prosecutions and improve the criminal justice system as a whole.

\section{DUTIES UNIQUE TO PROSECUTORS}

While the United States criminal justice system is undeniably adversarial, that does not mean that prosecutors are to handle cases with a win-at-all-costs approach. To the contrary, case law and ethical rules make clear that prosecutors must avoid approaching cases with such a mindset, and instead, they must strive for a fair and just resolution for every case.

Moreover, prosecutors in the United States have ethical duties that outsiders may view as antithetical to their duty to act as zealous advocates. For example, prosecutors are required to turn over to the defense both exculpatory evidence ${ }^{10}$ and evidence that may undermine the credibility of the government's witnesses. ${ }^{11}$ The United States Supreme Court made the fulfillment of these requirements even more onerous when it held that "the individual prosecutor has a duty to learn of any favorable evidence known to the others acting on the government's behalf in the case, including the police." ${ }^{\prime 2}$ The

8 U.S. Const., 4th Amend; Katz v. United States, 389 U.S. 347, 88 S.Ct. 507 (1967) (articulating the reasonable expectation of privacy standard).

9 Mapp v. Ohio, 367 U.S. 643, 81 S.Ct. 1684 (1961) (articulating the exclusionary rule).

10 Brady v. Maryland, 373 U.S. 83, 83 S.Ct. 1194 (1963).

11 Giglio v. United States, 405 U.S. 150, 92 S.Ct. 763 (1972).

12 Kyles v. Whitley, 514 U.S. 419, 437, 115 S.Ct. 1555, 1567 (1995). 
prosecutor must then turn over that evidence to the defense. And the prosecutor cannot escape responsibility for fulfillment of that duty by simply arguing that the police failed to bring the evidence to the prosecutor's attention; any such failure of the police is imputed to the prosecutor.

Each state has its own particular organization - commonly referred to as the "state bar" - responsible for the promulgation of ethical rules that govern the conduct of attorneys practicing within that particular jurisdiction. The codes of ethics established by each state are often influenced, directly or indirectly, by the Model Rules of Professional Conduct published by the American Bar Association ("ABA").

ABA Model Rule of Professional Conduct 3.8 sets forth special ethical duties for prosecutors that do not apply to other attorneys, including criminal defense attorneys. Those special duties include the following requirements (among others):

- To refrain from prosecuting a charge not supported by probable cause; ${ }^{13}$

- To make reasonable efforts to advise the accused of his or her right to an attorney;

- To disclose to the defense evidence that tends to negate the guilt of the accused;

- To limit extrajudicial statements (of the prosecutor and other law enforcement) that have a substantial likelihood of heightening public condemnation of the accused; and

- When the prosecutor knows of clear and convincing evidence ${ }^{14}$ a defendant in the prosecutor's jurisdiction was convicted of an offense that he or she did not commit, to seek to remedy the conviction.

\footnotetext{
13 Bordenkircher v. Hayes, 434 U.S. 357, 364, 98 S.Ct. 663, 668 (1978) ("In our federal system, so long as the prosecutor has probable cause to believe that the accused committed an offense defined by the statute, the decision whether or not to prosecute, and what charge to file or bring before a grand jury, generally rest entirely in his discretion."). "Probable cause exists where the facts and circumstances within their (the officers') knowledge and of which they had reasonably trustworthy information (are) sufficient in themselves to warrant a man of reasonable caution in the belief that' an offense has been or is being committed." Brinegar v. United States, 338 U.S. 160, 175, 69 S.Ct. 1302, 1310-11 (1949) (quoting Carroll v. United States, 267 U.S. 132, 162, 45 S.Ct. 280, 288 (1925)).

14 Clear and convincing evidence is evidence making the truth of factual contentions highly probable. See Colorado v. New Mexico, 467 U.S. 310, 316-17, 104 S.Ct. 2433, 2438 (1984).
} 
Returning to the example of prosecutors practicing law in the state of Nevada, most of these rules have been adopted and incorporated into Nevada Rule of Professional Conduct 3.8, which provides:

\section{Rule 3.8. Special Responsibilities of a Prosecutor.} The prosecutor in a criminal case shall:

(a) Refrain from prosecuting a charge that the prosecutor knows is not supported by probable cause;

(b) Make reasonable efforts to assure that the accused has been advised of the right to, and the procedure for obtaining, counsel and has been given reasonable opportunity to obtain counsel;

(c) Not seek to obtain from an unrepresented accused a waiver of important pretrial rights, such as the right to a preliminary hearing;

(d) Make timely disclosure to the defense of all evidence or information known to the prosecutor that tends to negate the guilt of the accused or mitigates the offense, and, in connection with sentencing, disclose to the defense and to the tribunal all unprivileged mitigating information known to the prosecutor, except when the prosecutor is relieved of this responsibility by a protective order of the tribunal;

(e) Not subpoena a lawyer in a grand jury or other criminal proceeding to present evidence about a past or present client unless the prosecutor reasonably believes:

(1) The information sought is not protected from disclosure by any applicable privilege;

(2) The evidence sought is essential to the successful completion of an ongoing investigation or prosecution; and

(3) There is no other feasible alternative to obtain the information;

(f) Except for statements that are necessary to inform the public of the nature and extent of the prosecutor's action and that serve a legitimate law enforcement purpose, refrain from making extrajudicial comments that have a substantial likelihood of heightening public condemnation of the accused and exercise reasonable care to prevent investigators, law enforcement personnel, employees or other persons assisting or associated with the prosecutor in a criminal case from making an extrajudicial statement that the prosecutor would be prohibited from making under Rule 3.6 or this Rule. 


\section{PROSECUTOR ACCOUNTABILITY}

Prosecutors who violate their ethical duties face potentially-devastating professional repercussions.

The same state bars discussed above are responsible for the discipline of attorneys, including prosecutors, who violate their ethical duties. As explained by the State Bar of Nevada, "[d]iscipline of lawyers in Nevada may take one of four forms depending on the particular circumstances and the severity of the offense":

1. A letter of reprimand which is kept on permanent file with the State Bar. This may be accompanied by a fine or restitution up to $\$ 1,000$;

2. A public reprimand which is published in the local newspapers and official State Bar publications;

3. Suspension of the lawyer's license to practice law; or

4. Disbarment. ${ }^{15}$

Principles of sovereign immunity often preclude additional measures to hold accountable those prosecutors who violate their ethical obligations, though such protections may not be as strong where the prosecutor acts in an investigative or administrative capacity. ${ }^{16}$ It should be noted, however, that provision of any such immunity has its critics. ${ }^{17}$

\footnotetext{
15 State Bar of Nevada website - https://www.nvbar.org/member-services-3895/ethics-discipline/ ethics-faqs/ (visited August 15, 2019).

16 See Imbler v. Pachtman, 424 U.S. 409, 422-23, 96 S.Ct. 984, 991 (1976) ("The common-law immunity of a prosecutor is based upon the same considerations that underlie the common law immunities of judges and grand jurors acting within the scope of their duties. These include concern that harassment by unfounded litigation would cause a deflection of the prosecutor's energies from his public duties, and the possibility that he would shade his decisions instead of exercising the independence of judgment required by his public trust."); Buckley v. Fitzsimmons, 509 U.S. 259, 1113 S.Ct. 2606 (1993) (recognizing that prosecutors are entitled to mere qualified immunity for actions taken in support of investigations and when making statements to the media, as opposed to the absolute immunity they enjoy when acting in their capacity as an advocate). Absolute immunity provides absolute protection from damages liability, while qualified immunity protects public officials from "damages liability for the performance of their discretionary functions when 'their conduct does not violate clearly established statutory or constitutional rights which a reasonable person would have known.'" Id., at 268, 113 S.Ct., at 2613 (quoting Butz v. Economou, 438 U.S. 478, 506, 98 S.Ct. 2894, 2911 (1978).

17 See e.g., Van Brunt, Alexa, Prosecutors shouldn't have immunity from their unethical - or unlawful - acts, The Guardian, February 5, 2015 (visited Aug. 18, 2019 - https://www.theguardian.com/ commentisfree/2015/feb/05/prosecutors-immunity-unethical-unlawful-acts).
} 
Additionally, prosecutors in the United States may find themselves in jail if they engage in egregious violations of their duty to seek justice; however, such prosecutions are exceedingly rare and the sparse history of such cases is unlikely to have much or a deterrent effect. ${ }^{18}$ For example, after Texas prosecutor Ken Anderson was found to be in contempt of court for withholding evidence favorable to the accused in a case that resulted in the accused spending nearly 25 years in prison for a murder he did not commit, Anderson was sentenced to a grand total of 10 days in jail. ${ }^{19}$

As the United States Supreme Court has recognized, "[t]here is no doubt that the breadth and discretion that our country's legal system vests in prosecuting attorneys carries with it the potential for both individual and institutional abuse. And broad though that discretion may be, there are undoubtedly constitutional limits upon its exercise. ${ }^{\prime 20}$ Should we continue to see stories of prosecutors abusing their authority, we should not be surprised if the public demands that current immunity protections be stripped away. In order to avoid this predicament, unethical prosecutors must be held accountable for their unethical conduct.

\section{FINAL CONSIDERATIONS}

Public prosecutors in the United States play several roles in the criminal justice system. Their conduct in carrying out these roles along with the conduct of the police - will determine the public's level of confidence in the criminal justice system. As recent protests aimed at law enforcement show, shifts in policy are needed in order to maintain adequate public confidence in the criminal justice system. Public prosecutors who lead prosecuting agencies and fail to adapt

18 Lindell, Chuck, Ken Anderson gets 10-day sentence, surrenders law license, Statesman, Updated Sept. 252018 (visited Aug. 18, 2019 - https://www.statesman.com/article/20131109/NEWS/311099700). 19 Id.

20 Bordenkircher, 434 U.S., at 365, 98 S.Ct., at 669. 
to the public's demands will likely be replaced by public prosecutors who are open to the shifts in policy called for by the voters.

\section{O PAPEL DO PROMOTOR PÚBLICO NOS ESTADOS UNIDOS}

\section{RESUMO}

Promotores nos Estados Unidos desempenham papéis multifacetados em seu sistema de justiça criminal. Eles fornecem orientação durante as etapas investigativas dos casos, lideram a acusação de casos nos processos contrários ao Estado, corrigem sua própria profissão e lideram os esforços legislativos destinados a tornar o sistema mais justo para todos os envolvidos. Existem promotores diferentes para cada soberania localizada pelo país. Estatutos, constituições e jurisprudência estabelecem os direitos e deveres de cada um desses gabinetes. Todos os promotores públicos nos Estados Unidos compartilham a busca pela justiça como seu objetivo comum.

Palavras-chave: Procurador. Estados Unidos. Nevada. Las Vegas.

\section{REFERENCES}

\section{$\operatorname{Article(s)}$}

Lindell, Chuck. Ken Anderson gets 10-day sentence, surrenders law license, Statesman, Updated Sept. 252018 (visited Aug. 18, 2019 - https:// www.statesman.com/article/20131109/NEWS/31 1099700) Van Brunt, Alexa. Prosecutors shouldn't have immunity from their unethical - or unlawful - acts, The Guardian, February 5, 2015 (visited Aug. 18, 2019 - https://www.theguardian.com/commentisfree/2015/ feb/05/prosecutors-immunity-unethical-unlawful-acts) 


\section{Case(s)}

Berger v. United States, 295 U.S. 78, 55 S.Ct. 629 (1935)

Bordenkircher v. Hayes, 434 U.S. 357, 98 S.Ct. 663 (1978)

Brady v. Maryland, 373 U.S. 83, 83 S.Ct. 1194 (1963)

Brinegar v. United States, 338 U.S. 160, 69 S.Ct. 1302 (1949)

Buckley v. Fitzsimmons, 509 U.S. 259, 1113 S.Ct. 2606 (1993)

Butz v. Economou, 438 U.S. 478, 506, 98 S.Ct. 2894, 2911 (1978)

Carroll v. United States, 267 U.S. 132, 45 S.Ct. 280, (1925)

Colorado v. New Mexico, 467 U.S. 310, 104 S.Ct. 2433 (1984)

Giglio v. United States, 405 U.S. 150, 92 S.Ct. 763 (1972)

Imbler v. Pachtman, 424 U.S. 409, 422-23, 96 S.Ct. 984 (1976)

Katz v. United States, 389 U.S. 347, 88 S.Ct. 507 (1967)

Kyles v. Whitley, 514 U.S. 419, 115 S.Ct. 1555 (1995)

Mapp v. Ohio, 367 U.S. 643, 81 S.Ct. 1684 (1961)

\section{Constitutional Provision(s)}

U.S. Constitution, 4th Amendment

\section{Principles of the Law}

American Bar Association. Criminal Justice Standards for the Prosecution Function (4th ed.)

United Nations Office on Drugs and Crime. The Status and Role of Prosecutors: A United Nations Office on Drugs and Crime and International Association of Prosecutors Guide (2014)

\section{Statute(s)}

28 United States Code § 541

Nevada Revised Statute § 228.020

\section{Webpage(s)}

State Bar of Nevada website - https://www.nvbar.org/memberservices-3895/ethics-discipline/ethics-faqs/ (visited August 15, 2019) 